\title{
Profiles of cytokines secreted by isolated human endometrial cells under the influence of chorionic gonadotropin during the window of embryo implantation
}

\author{
Akhilesh Srivastava', Jayasree Sengupta ${ }^{1,3}$, Alka Kriplani $^{2}$, Kallol K Roy ${ }^{2}$ and Debabrata Ghosh ${ }^{1 *}$
}

\begin{abstract}
Background: Several studies have indicated that human pre-implantation embryo-derived chorionic gonadotropin (hCG) may influence the implantation process by its action on human endometrial epithelial and stromal cells. Despite reports indicating that $\mathrm{hCG}$ acts on these cells to affect the production of several cytokines and growth factors (e.g., MIF, IGF-I, VEGF, LIF, IL-11, GMCSF, CXL10 and FGF2), our understanding of the integral influence of hCG on paracrine interactions between endometrial stromal and epithelial cells during implantation is very limited.

Methods: In the present study, we examined the profile of 48 cytokines in the conditioned media of primary cell cultures of human implantation stage endometrium. Endometrial epithelial cells (group $1 ; n=20$ ), stromal cells (group $2 ; n=20$ ), and epithelial plus stromal cells (group $3 ; n=20$ ) obtained from mid-secretory stage endometrial samples $(n=60)$ were grown on collagen and exposed to different doses $(0,1,10$ and $100 \mathrm{lU} / \mathrm{ml})$ of rhCG for $24 \mathrm{~h}$ in vitro. Immunochemical and qRT-PCR methods were used to determine cytokine profiles. Enrichment and process networks analyses were implemented using a list of cytokines showing differential secretion in response to hCG.
\end{abstract}

Results: Under basal conditions, endometrial epithelial and stromal cells exhibited cell type-specific profiles of secreted cytokines. Administration of hCG (100 IU) resulted in significantly $(P<0.05)$ different cytokine secretion profiles indicative of macropinocytic transport (HGF, MCSF) in epithelial cells, signal transduction (CCL4, FGF2, IL-1b, IL-6, IL-17, VEGF) in stromal cells, and epithelial-mesenchymal transition (FGF2, HGF, IL-1b, TNF) in mixed cells. Overall, the administration of hCG affected cytokines involved in the immune response, chemotaxis, inflammatory changes, proliferation, cell adhesion and apoptosis.

Conclusions: CG can influence the function of the endometrium during blastocyst implantation via its differential action on endometrial epithelial and stromal cells. CG may also affect complex paracrine processes in the different endometrial cell types.

Keywords: Cell culture, Cytokines, Endometrium, Epithelial cells, hCG, Immunoblot, Multiplexing, RT-PCR, Stromal cells

\section{Background}

Blastocyst implantation in humans involves a complex process that occurs during the mid-luteal phase of the menstrual cycle when the maternal endometrium becomes receptive and the blastocyst becomes free of the zona pellucida and invades the endometrium. There is

\footnotetext{
* Correspondence: debabrata.ghosh1@gmail.com

'Department of Physiology, All India Institute of Medical Sciences, New Delhi, India

Full list of author information is available at the end of the article
}

substantial evidence to suggest that mutual interaction between pre-implantation stage endometrium and the embryo plays a critical role in this process [1]. One of the factors that may potentially influence the biology of the peri-implantation stage endometrium is human chorionic gonadotropin (hCG) [1], which may be secreted by the human pre-implantation embryo $[2,3]$ and implantation-stage human endometrium [4,5]. This secretion profile of hCG is supported by the observation that in the secretory phase, epithelial and stromal cells

\section{Biomed Central}


from the human endometrium express receptors for hCG [6,7]. Furthermore, it has been demonstrated that the administration of hCG can influence endometrial functions in various experimental models [7-13].

Our understanding of the integral influence of hCG in paracrine interactions between endometrial stromal and epithelial cells during implantation is limited. In a recent study, Paiva et al. [14] examined the effect of hCG (0.2, 2 and $20 \mathrm{IU} / \mathrm{ml}$ ) administered to human endometrial epithelial cells in vitro and observed that recombinant hCG stimulated the secretion of six analytes (VEGF, LIF, IL-11, GMCSF, CXL10 and FGF2). However, hCG acts on human endometrial stromal cells to promote a variety of functions that include stimulation of production of the multi-functional cytokine, macrophage inhibitory factor (MIF) [9], suppression of the cellular apoptotic machinery $[15,16]$, and reduction in insulin-like growth factor-I (IGF-I) and interferon-gamma-mediated responsiveness of stromal decidual cells [11,17]. Nonetheless, the responsiveness of human endometrial stromal cells and epithelial cells to hCG remains undefined mainly for two reasons. First, the endometrial cells used in previous studies were grown on a conventional two-dimensional plastic substratum, which typically fails to support a physiological phenotype. Several studies have indicated that a three-dimensional culture system is a better model in this regard [18-20]. Also, the integral influence of paracrine interactions between stromal and epithelial cells in mediating hCG effects has not been reported [20]. In the present study, we addressed these issues through the multi-analyte profiling of 48 cytokines, chemokines and growth factors. The secretion of these factors was assessed in the conditioned media of threedimensional primary cell cultures of human endometrial epithelial cells, stromal cells, and epithelial plus stromal cells isolated from endometrial biopsies collected during the 'window' of implantation. These cell types were grown on collagen-I biomatrix and exposed to different doses of hCG. The cytokines, chemokines and growth factors investigated in the study have been previously reported to be synthesised and secreted by the human endometrium [21].

\section{Methods}

\section{Patients and tissue collection}

This study was approved by the Ethics Committee of the All India Institute of Medical Sciences (AIIMS) and conducted in accordance with the Helsinki Declaration. Sixty pre-menopausal women (mean age: $28 \pm 4$ years; BMI: $18.9-22.8 \mathrm{~kg} / \mathrm{m}^{2}$ ) with regular menstrual cycles (30 \pm 2 days) attending the out-patient fertility clinic of the Department of Obstetrics and Gynaecology, AIIMS, were selected for the present study. The women underwent dilation and curettage to collect endometrial tissue samples for diagnostic gynaecological procedures and were a priori screened to determine whether they were negative for pregnancy and tuberculosis. Also, these women had not received any steroid treatment for at least 4 months prior to tissue collection and were not suffering from any endocrine disorder or systemic disease. Randomly chosen pieces of sample were provided to us, and all women provided written informed consents to participate in the study. The tissue samples were collected on ice in sterile DMEM:F12 (1:1) medium containing 5\% (v/v) FCS, gentamicin $(10 \mu \mathrm{g} / \mathrm{ml})$, penicillin $(100 \mathrm{IU} / \mathrm{ml})$, streptomycin $(100 \mu \mathrm{g} / \mathrm{ml})$ and fungizone $(2.5 \mu \mathrm{g} / \mathrm{ml})$ and were immediately transported on ice to the cell culture laboratory for further processing.

Each fresh specimen was washed three times in icecold sterile HBSS supplemented with antibiotics and an antimycotic agent to remove blood and secretions and were randomly divided into two parts. One small section was washed in phosphate buffer saline ( $\mathrm{pH} 7.4)$ and fixed in ice-cold neutral buffered paraformaldehyde (4\% w/v), pH 7.4, for histological assessment, and the residual tissue was processed for tissue dissociation and cell separation as described below.

\section{Cell isolation and separation}

Enzymatic dissociation of endometrial tissue followed by cell separation was performed using previously described standardised procedures $[19,22,23]$. Briefly, the endometrial specimen was washed in HBSS, minced and incubated at $37^{\circ} \mathrm{C}$ with collagenase III $(0.2 \%, \mathrm{w} / \mathrm{v})$ in HBSS supplemented with $2 \%(\mathrm{v} / \mathrm{v})$ foetal calf serum (FCS), $15 \mathrm{mM}$ HEPES (N-2-hydroxyethyl-piperazine-N'-2-ethanesulfonic acid), 1X antibiotic-antimycotic solution [penicillin (100 IU/ml), streptomycin $(100 \mu \mathrm{g} / \mathrm{ml})$ and fungizone $(2.5 \mu \mathrm{g} / \mathrm{ml})]$ and gentamicin $(10 \mu \mathrm{g} / \mathrm{ml})$ for 30 minutes with shaking at $50 \mathrm{rpm}$. The final cell suspension contained primarily single stromal cells and fragments of glands. The cell suspension was washed three times with $\mathrm{Ca}^{++} / \mathrm{Mg}^{++}$-free HBSS supplemented with the antibiotic/ antimycotic mixture (HBSS-mod) and filtered through a sterile, pre-equilibrated mesh filter $(51 \mu \mathrm{m})$. The filtrate contained the 'stromal cell enriched' fraction. The residual 'epithelial cell enriched' fraction was further purified by unit gravity sedimentation in $10 \%(\mathrm{v} / \mathrm{v})$ FBS. The stromal cells remained in cell suspension, and the sediment, consisting of sheets, fragments and clumps of epithelial cells, was collected and washed three times with HBSS-mod. The 'epithelial cell fraction' was further enriched by density-dependent fractionation on a discontinuous Percoll gradient as described previously $[19,22,23]$. The 'epithelial cell enriched fraction' was resuspended in complete medium (DMEM:F12 with 10\% FCS) and stored on ice. 
The 'stromal cell enriched fraction' was further enriched by density-dependent fractionation on a discontinuous Percoll gradient as described previously [19,22,23]. CD45positive leucocytes were depleted using anti-CD45 MACS microbeads and LS magnetic separation columns in a MidiMACS separator (Miltenyi Biotec, Bergisch Gladbach, Germany) as described [24]. The negative fraction containing the stromal cell-enriched population was washed twice with HBSS-mod at $300 \times \mathrm{g}$ for 10 minutes and resuspended in $1 \mathrm{ml}$ of complete medium (DMEM:F12 with $10 \%$ FCS) and kept on ice. For separated mixed cells, endometrial cells separated by enzymatic digestion were not passed through a mesh filter, but the remaining steps were followed as described above. The yield and viability of the isolated cells were determined using standard protocols [24]. The relative abundance of cytokeratin-positive, vimentin-positive, CD45-positive and vW factor-positive cells in all three groups was determined using standard immunocytochemical procedures [25].

\section{Primary culture of human endometrial cells}

Primary cell cultures at $1 \times 10^{5}$ cells $/ \mathrm{cm}^{2}$ were separated into three different groups: Group 1: epithelial cells $(\mathrm{n}=$ 20), Group 2: stromal cells $(n=20)$, and Group 3: mixed cells $(n=20)$. All three groups were cultured in DMEM: F12 (1:1) medium containing 10\% (v/v) FCS, gentamicin $(10 \mu \mathrm{g} / \mathrm{ml})$, penicillin $(100 \mathrm{IU} / \mathrm{ml})$, streptomycin $(100 \mu \mathrm{g} / \mathrm{ml})$ and fungizone $(2.5 \mu \mathrm{g} / \mathrm{ml})$ in a $5 \% \mathrm{CO}_{2}$ atmosphere at $37^{\circ} \mathrm{C}$ on rat-tail collagen type I as described previously [19,22,23]. Briefly, rat-tail collagen was extracted from tendon bundles of sterilised rat tails in sterile diluted $(1: 1,000)$ acetic acid at $4^{\circ} \mathrm{C}$, and the acid-soluble collagen $(2.0 \pm 0.2 \mathrm{mg} / \mathrm{ml})$ was collected aseptically and used as stock as previously described $[19,22]$. Collagen biomatrix was generated by neutralising acid collagen with $0.34 \mathrm{~N} \mathrm{NaOH}$ and diluted with $10 \mathrm{X}$ medium to a concentration of $1.2 \pm 0.1 \mathrm{mg} / \mathrm{ml}$ at $\mathrm{pH} 7.4$ on ice and then gelled at $37^{\circ} \mathrm{C}$ with $5 \%$ carbon dioxide $[19,22]$. Cells were allowed to attach with a daily change of medium; at 72 hours when cells had grown to $\approx 80 \%$ confluence, serum-free DMEM:F12 (1:1) medium supplemented with insulin $(10 \mu \mathrm{g} / \mathrm{ml})$, transferrin $(5.5 \mu \mathrm{g} / \mathrm{ml})$, selenium $(6.7 \mathrm{ng} / \mathrm{ml})$, hydrocortisone $(5 \mu \mathrm{g} / \mathrm{ml})$, gentamicin $(10 \mu \mathrm{g} / \mathrm{ml})$, penicillin $(100 \mathrm{IU} / \mathrm{ml})$, streptomycin $(100 \mu \mathrm{g} / \mathrm{ml})$ and fungizone $(2.5 \mu \mathrm{g} / \mathrm{ml})$ (designated as basal condition) was added. Serum-free cell cultures in all three groups were exposed to different concentrations $(0,1,10,100 \mathrm{IU} / \mathrm{ml})$ of rhCG in triplicate. After 24 hours, cultures were terminated, and gels containing cells were used for RNA extraction and quantitative gene expression using RT-PCR. The remaining conditioned media were collected and centrifuged at $10,000 \times \mathrm{g}$ for 5 minutes, and the supernatant was stored at $-80^{\circ} \mathrm{C}$ for immunoassay of multiple cytokines and immunoblotting experiments. Five replicates in duplicate were conducted for each set of experiments.

\section{hCG binding to isolated endometrial cells}

Different sets $(n=3)$ of experiments were performed to examine the binding of biotinylated rhCG to the cells grown in culture. Biotin labelling of hCG was performed using a commercially available biotin labelling kit from Thermo Scientific (Rockford, IL, USA) according to the manufacturer's protocol. Isolated endometrial cells were grown separately on collagen-coated cover slips in DMEM:F12 complete medium as described above. The cells were then washed twice in serum-free DMEM:F12 and exposed to biotinylated rhCG $(200 \mathrm{mIU} / \mathrm{ml})$ at $37^{\circ} \mathrm{C}$ in a humidified incubator with $5 \% \mathrm{CO}_{2}$ for 40 minutes; these parameters were determined based on initial optimisation with three concentrations (100, 200 and $400 \mathrm{mIU} / \mathrm{ml}$ ) of biotinylated rhCG and two time points (20 minutes and 40 minutes). To assess the specificity of hCG binding, parallel cultures of attached cells after 72 hours of culture were incubated with biotinylated scrambled sham rhCG, unconjugated biotin, unconjugated rhCG in place of biotinylated rhCG or without any of these reagents. The incubation was stopped with ice-cold PBS, and the cells were fixed in $4 \%(\mathrm{w} / \mathrm{v})$ paraformaldehyde to assess the bound hCG by immunofluorescence using an Alexa488-conjugated anti-biotin monoclonal antibody and a Confocal Laser Scanning Microscope (DMIRE2, Leica Microsystems, Wetzlar GmbH, Germany) [24,25].

\section{Multiplex assays of cytokines in conditioned media}

The concentrations of 48 cytokines, chemokines and growth factors (for details, see Additional file 1: Table S1) that have been reported to be synthesised and secreted by the human endometrium [21] were analysed. Cell culture supernatants were assessed by quantitative cytokine assays using a Bioplex ${ }^{\mathrm{TM}}$ Pro-human cytokine 27-plex panel and a cytokine 21-plex panel based on xMAP technology (Bio-Rad Laboratory, Hercules, CA, USA) according to the pre-optimised protocol. Briefly, antibody-conjugated beads were added to individual wells of a 96-well filter plate and adhered using vacuum filtration. After washing, $50 \mu \mathrm{l}$ of prediluted standards or serum were added, and the filter plate was shaken at $300 \mathrm{rpm}$ for 30 minutes at room temperature. A prediluted multiplex biotinconjugated detection antibody was then added for 30 minutes. Prediluted streptavidin-conjugated PE was added followed by an additional wash and the addition of Bio-Plex assay buffer. The filter plate was analysed, and concentrations of each cytokine were determined using the BioRad BioPlex 200 instrument equipped with BioManager v6.0 software (Bio-Rad). All samples were run in duplicate. Standard curves were generated for each biomarker. Goodness of fit for standard curves was determined by the standard recovery method and by calculating the concentration of each standard [26]. 


\section{Western blotting}

Based on the post-hoc analysis of the immunoassays as described below, 13 proteins (CCL2, CCL4, FGF2, GMCSF, IFNG, IL-6, IL-12p35, IL-12p70, LIF, LTA, PDGFbb, TNF and VEGF) were chosen as target candidates, and their expression in conditioned medium ( $\mathrm{n}=3$ each) was assessed in $20 \mu \mathrm{g}$ protein lysate samples along with the pre-stained molecular weight marker. Samples were assessed by SDS-PAGE and subsequent Western immunoblotting techniques on a nitrocellulose membrane and chemicals obtained from Bio-Rad (Hercules, CA, USA) [24]. The details of the antibodies used are given elsewhere (see Additional file 2: Table S2). Final visualisation was achieved using Vectastain $A B C$ immunoperoxidase kits (Vector Laboratories, Burlingame, CA, USA). Respective primary and secondary antibody controls were run simultaneously to examine the specificity of the antibodies. The molecular weights and semi-quantitative analysis of the bands were determined using densitometric equipment (Pharos FX Plus Molecular Imager, Bio-Rad, Hercules, CA, USA) and optimised densitometric analysis software (PD Quest Advanced, BioRad). The integrated measures of optical densities for individual antigens were calculated from the $\log$ of transmittance for each target antigen and normalised to total secreted protein (in micrograms).

\section{Quantitative real time RT-PCR}

The relative expression of 17 genes (CCL2, CCL3, CCL5, CXCL10, FGF2, GCSF, GMCSF, IFNG, IL-1b, IL-6, IL-13, IL-16, IL-17, LIF, PDGFB, TNF and VEGF) selected as targets from the post-hoc analysis (as described below) of the BioPlex cytokine data was examined. All samples were assessed using glyceraldehyde 3-phosphate dehydrogenase (GAPDH) as an endogenous control and SYBR Green-based quantitative RT-PCR as described previously [27]. Briefly, total RNA was extracted using Trizol (Agilent Technologies Singapore Pvt. Ltd., Shung Avenue, Singapore), purified with DNase I (Sigma Chemical Co., St. Louis, Missouri, USA) and subjected to re-extraction when necessary. The yield and purity of the extracted RNA were verified using standard spectrophotometric methods and $1 \%$ agarose gel electrophoresis [27]. Furthermore, the RIN score of individual samples was determined using the Agilent 2100 Bioanalyzer, RNA 6000 NanoLabChip kit and Agilent 2100 Expert Software (Agilent Technologies, Inc., Santa Clara, CA, USA) [28]. Four samples that failed to yield either sufficient amounts of RNA or an acceptable RIN score (>8.0) were not included. For the real time RTPCR, the first-strand cDNA was synthesised from $2 \mu \mathrm{g}$ of total RNA with an optimised RevertAid ${ }^{\text {Tx }}$ First Strand cDNA Synthesis Kit (Fermentas, Germany), and the PCR was performed using Maxima ${ }^{\text {Tu }}$ SYBR Green/Fluorescein
qPCR Master Mix (Fermentas, Germany) and forward and reverse primers for the respective genes.

The primers for the target genes were designed using Beacon Designer software (Labware Scientific Inc., USA) as shown in Additional file 3: Table S3 and obtained from Integrated DNA Technologies (Coralville, Iowa, USA) for target genes. The reaction was performed on a BioRad platform (iCycleriQTm Real time PCR detection system, BioRad, Hercules, CA, USA) using an optimised protocol [27]. Cycle threshold values were obtained, and $\Delta \mathrm{Ct}$ values between the experimental and normalised $\mathrm{Ct}$ were determined. The relative expression ratios between groups from cycle threshold $(\mathrm{Ct})$ values and absolute values were determined as described previously [27].

\section{Data analysis}

Profiles of factors from the immunoassay data were classified into six scales depending on factor concentrations as follows (pg per microgram of protein): $0, \leq 0.05 ; 1,>0.05$ to $0.1 ; 2,>0.1$ to $1.0 ; 3,>1.0$ to $10.0 ; 4,>10.0$ to 100.0 ; $5,>100.0$. Due to individual variability, data were normalised with the mean basal values from the zero hCG group as the internal control. The quantitative values of factors in medium and transcripts in cells from each culture group with different doses of hCG were $\log$ transformed and analysed using the KruskalWallis test followed by the Wilcoxon Signed Ranks test. Significant changes were derived for each bin showing $\mathrm{P}<0.05$.

\section{Enrichment and process networks analysis}

For post-hoc enrichment analysis, candidate products were matched with known products into functional ontologies for 'common', 'similar' and 'unique' sets. The probability of a random intersection between a candidate on the target list and ontology entities was estimated in terms of p-values. A lower p-value meant higher relevance of the entity to the dataset due to a higher rating for the entity. Enrichment analyses were performed using a cutoff threshold $(\operatorname{pFDR}(\mathrm{p})=0.05)$ for the cytokines, chemokines and growth factors showing differential secretion in response to rhCG to identify the enriched biological pathways. Furthermore, the uploaded files of the input list of cytokines, chemokines and growth factors showing differential secretion in response to hCG were used for the generation of biological networks. The Analyze Networks (AN) algorithm with default settings was used to retrieve interaction networks that were potentially influenced by hCG. In this workflow, the networks were prioritised based on the number of canonical pathways in the network. The enrichment analysis and network constructions were achieved using a Metacore bioinformatics platform (GeneGo, St. Joseph, MI, USA) [29]. 


\section{Results}

Characterisation of isolated cells in culture

The procedure used in the present study yielded $>93 \%$ viable cells. Figure 1 (A-L) shows representative microphotographs of cytokeratin (Figure 1A-C), vimentin (Figure 1D-F), CD45 (Figure 1G-I) and $\mathrm{vW}$ factor (Figure 1J-L) localisation in attached epithelial, stromal and mixed cells 72 hours after seeding. The washed 'enriched epithelial cell' fraction yielded $88( \pm 2) \%$ cytokeratin-positive epithelial cells, and the CD45-negative fraction contained the 'enriched stromal cell' population that yielded $92( \pm 4) \%$ vimentinpositive stromal cells. Generally, there were no CD45- and $\mathrm{vW}$ factor-positive cells after attachment (Figure 1G-L). The endometrial mixed cells used in the study typically constituted $30( \pm 4) \%$ cytokeratin-positive epithelial cells and $70( \pm 4) \%$ vimentin-positive stromal cells. Figure 1 (M-O) shows the pattern of hCG binding following exposure to biotinylated rhCG $(200 \mathrm{mIU} / \mathrm{ml})$ in epithelial cells, stromal cells and mixed cells at 72 hours in primary culture when the cells were subjected to hCG.

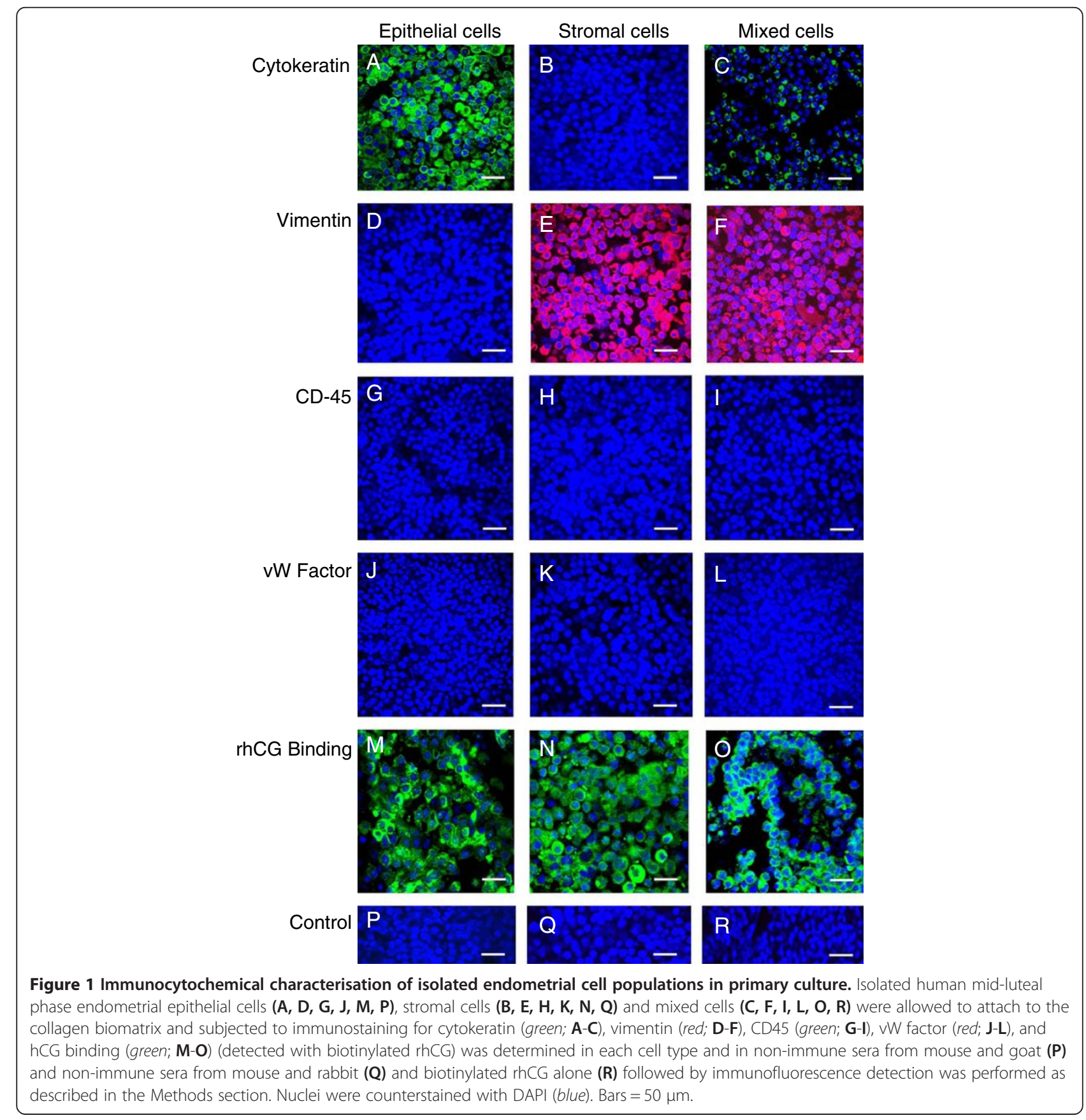




\section{General profile of secreted cytokines}

The detailed profile of cytokines secreted from the three groups of cells under basal conditions (serum-free DMEM:F12 (1:1) medium supplemented with insulin $(10 \mu \mathrm{g} / \mathrm{ml})$, transferrin $(5.5 \mu \mathrm{g} / \mathrm{ml})$, selenium $(6.7 \mathrm{ng} / \mathrm{ml})$, hydrocortisone $(5 \mu \mathrm{g} / \mathrm{ml})$, gentamicin $(10 \mu \mathrm{g} / \mathrm{ml})$, penicillin $(100 \mathrm{IU} / \mathrm{ml})$, streptomycin $(100 \mu \mathrm{g} / \mathrm{ml})$ and fungizone $(2.5 \mu \mathrm{g} / \mathrm{ml})$ ) is shown in the supplementary table (see Additional file 4: Table S4). In these conditions, endometrial cells in all three groups secreted more than $1 \mathrm{pg} / \mu \mathrm{g}$ protein levels of CCL4, CCL5, CXCL9, CXCL12, FGF2, GMCSF, HGF, IL-2ra, IL-6, IL-12p40, MCSF, MIF, and VEGF. Additionally, endometrial epithelial cells in group 1 secreted substantial amounts of CCL3, CCL7, CXCL1, CXCL10, IFNG, IL-1ra, IL-12p70, LIF, PDGFbb and SCGF; these cytokines were either not detectable or there was less than $1 \mathrm{pg} / \mu \mathrm{g}$ in the other two groups. CCL2 and IL-8 were secreted at $>1 \mathrm{pg} / \mu \mathrm{g}$ of total secreted protein by endometrial stromal cells (group 2) and mixed cells (group 3) but not by endometrial epithelial cells (group 1). Both endometrial epithelial cells and stromal cells failed to secrete detectable levels of CCL27, GCSF, IL-2, IL-4, IL-7, IL-9, IL-10, IL-15, IL-18, bNGF, SCF, and LTA under basal conditions. Of these twelve cytokines, endometrial mixed cells did not show detectable levels of seven of the cytokines (CCL27, IL-10, IL-15, IL-18, bNGF, SCF, and LTA) and had negligible ( $>0.1 \mathrm{pg} / \mu \mathrm{g}$ protein) amounts of IL-2, IL-4 and IL-7; however, endometrial mixed cells secreted substantial amounts of GCSF ( $>10 \mathrm{pg} / \mu \mathrm{g}$ protein) and IL-9 (>1 pg/ $/ \mathrm{g}$ protein). Endometrial epithelial cells did not secrete detectable CCL2, and stromal cells did not secrete detectable CCL3, CCL7, IL-12p70, IL-13, PDGFbb, and TNF levels. In endometrial mixed cells, CCL7, IL-12p70 and PDGFbb were not detectable, and CCL3, IL-13 and TNF were detectable at very low concentrations $(<1 \mathrm{pg} / \mu \mathrm{g}$ protein $)$.

\section{Differential cytokine secretion profile following hCG administration}

Statistical analyses failed to identify any significant change between administration of $0 \mathrm{IU} / \mathrm{ml}$ and $1 \mathrm{IU} / \mathrm{ml}$ or between $10 \mathrm{IU} / \mathrm{ml}$ and $100 \mathrm{IU} / \mathrm{ml}$ of rhCG; however, there was a significant difference between administration of $0 / 1$ IU and 100 IU of rhCG in group 1 (epithelial cells), 2 (stromal cells) and 3 (mixed cells) cells in the production of a large number of cytokines. Table 1 gives a summary of the fold change in the concentrations of secreted cytokines as assessed by quantitative multiplex assays using conditioned media from the three groups of cells following $100 \mathrm{IU} / \mathrm{ml}$ of rhCG treatment.

\section{Immunochemical and transcript analyses}

Marked concordance was observed between estimates of changes in concentrations obtained from multiplex
Table 1 Fold-change (at $P<0.05$ ) observed in secreted cytokines, chemokines and growth factors from isolated endometrial cells following administration of recombinant hCG $(100 \mathrm{lU} / \mathrm{ml})$ in three culture groups

\begin{tabular}{|c|c|c|c|}
\hline \multirow[t]{3}{*}{ Name } & \multicolumn{3}{|c|}{ Groups (Cell type) } \\
\hline & 1 & 2 & 3 \\
\hline & (Epithelial) & (Stromal) & (Mixed) \\
\hline$\overline{C C L 2}{ }^{\prime}$ & (1) & - & - \\
\hline $\mathrm{CCL}^{2}$ & - & - & $(+) 8.0$ \\
\hline CCL4 & $(+) 1.7$ & $(+) 1.5^{5}$ & $(+) 8.0$ \\
\hline$C C L 5^{2}$ & $(+) 1.8$ & - & $(+) 2.8$ \\
\hline CCL7 & $(-) 1.7$ & - & - \\
\hline CXCL1 & $(-) 6.5$ & - & - \\
\hline CXCL9 & - & - & $(-) 1.7$ \\
\hline CXCL10 $0^{3}$ & - & - & $(+) 2.7$ \\
\hline CXCL12 & $(-) 2.1$ & - & - \\
\hline$F G F 2^{3}$ & - & $(+) 1.5$ & $(+) 2.3$ \\
\hline$G_{C S F}^{2}$ & - & - & $(+) 1.4$ \\
\hline GMCSF $^{3}$ & - & $(+) 1.5$ & $(+) 2.7$ \\
\hline$H G F$ & $(-) 1.6$ & - & $(-) 1.7$ \\
\hline$I_{F N G^{2}}$ & - & $(+) 1.5$ & $(+) 2.0$ \\
\hline $1 L-1 b^{7}$ & - & $(+) 2.7$ & $(+) 3.3$ \\
\hline$I L-6^{2}$ & $(+) 2.1$ & $(-) 1.6$ & $(-) 2.3$ \\
\hline IL-8 & - & - & $(-) 2.6$ \\
\hline IL-12p40 & $(-) 1.5$ & - & - \\
\hline$I L-12 p 70$ & - & - & ( 1$)$ \\
\hline $1 L-13^{2}$ & - & - & $(+) 1.8$ \\
\hline $1 L-16^{1}$ & - & $(-) 2.7$ & $(-) 1.8$ \\
\hline $1 L-17^{2}$ & - & $(+) 2.1$ & - \\
\hline LIF $^{4}$ & $(+) 1.5$ & & $(+) 1.7$ \\
\hline MCSF & $(-) 1.5$ & - & $(-) 1.6$ \\
\hline MIF & $(+) 1.7$ & $(-) 1.5$ & $(-) 2.4$ \\
\hline$P^{\prime} G F B B^{l}$ & - & - & ( \\
\hline SCGF & $(-) 3.5$ & - & - \\
\hline$T N F^{2}$ & - & - & $(+) 1.7$ \\
\hline TRAIL & $(+) 1.5$ & - & $(-) 1.6$ \\
\hline$V E G F^{\prime}$ & - & $(+) 1.9$ & $(+) 2.5$ \\
\hline
\end{tabular}

, no change. ( $(\mathrm{l})$, infinitesimally increased because of non-detectable amount under the basal condition. (), up-regulated. ( ) down-regulation. The cytokines which were subjected to Western blot analysis are shown in bold, and the ones which were subjected to quantitative real time RT-PCR for estimation of relative abundance of transcripts are shown in italics.

${ }^{1}$ did not show significant concordance between immunopositive protein concentration in medium and relative abundance of transcripts for all cell culture groups (groups 1-3).

${ }^{2}$ showed significant $(P<0.05)$ concordance between immunopositive protein concentration in medium and relative abundance of transcripts for all cell culture groups (groups 1-3).

${ }^{3}$ showed significant $(P<0.05)$ concordance between immunopositive protein concentration in medium and relative abundance of transcripts for epithelial cells (group 1) and mixed cells (group 3), but not for stromal cells (group 2). 4 showed significant $(P<0.05)$ concordance between immunopositive protein concentration in medium and relative abundance of transcripts for stromal cells (group 2) and mixed cells (group 3), but not for epithelial cells (group 1). ${ }^{5}$ no concordance was seen between profiles from multiplex based immunoassay and from densitometric analysis of Western immunoblot. 
immunoassays and from Western blot analyses for thirteen cytokines. An exception was CCL4 in the conditioned media of stromal cells in which a positive significant change following 100 IU of hCG administration was demonstrated in multiplex assays, but no detectable change was observed in the Western immunoblot analysis (Table 1). Figure 2 shows representative Western blot images for the cytokines with significant changes in expression $(\mathrm{P}<0.05)$.

On the other hand, the expression of seventeen genes based on quantitative real time RT-PCR revealed marked variation between changes in protein secretory profiles and the relative abundance of transcripts in the cells following treatment with $\mathrm{rhCG}(100 \mathrm{IU} / \mathrm{ml})$. Figure 3 shows a graphical comparison of the changes observed in cytokine protein levels in the conditioned media and in the relative abundance of transcripts of these cytokines, chemokines and growth factors in the cultured cells; the data demonstrated a significant increase in the cytokine transcript levels following treatment with 100 IU rhCG compared with that in the basal condition.

Enrichment analysis and biological networks construction Table 2 shows the summary of the enrichment analysis for the candidate cytokines, chemokines and growth factors showing differential $(\geq 1.5)$ secretion at $\mathrm{P}<0.05$ following the administration of hCG in all three cell

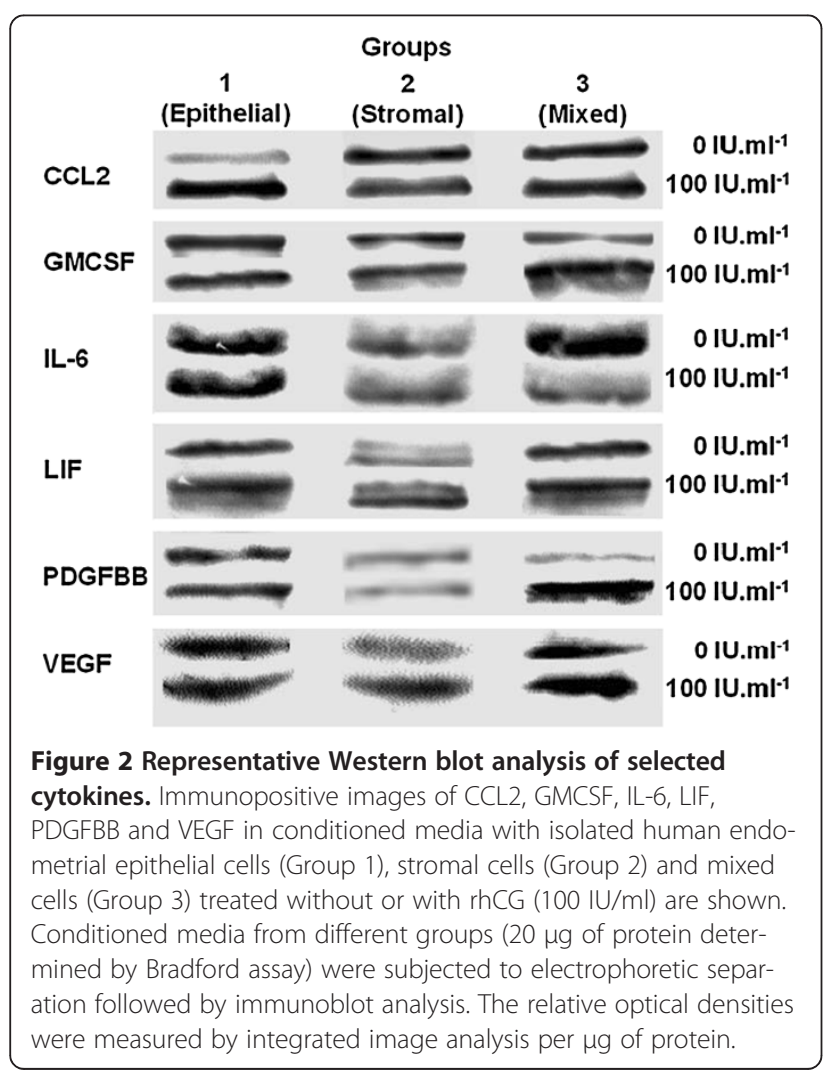

culture groups. The integral modules that were affected by hCG treatment were immune response, chemotaxis, inflammatory changes, proliferation, cell adhesion and anti-apoptosis. It is notable that the hierarchical analysis of pathways and GO processes indicated a differential behaviour among epithelial, stromal and mixed cells upon treatment with hCG (Table 2).

\section{Discussion}

The cells in the three culture groups showed differential profiles of cytokine, chemokine and growth factor secretion in the present study. Table 3 provides a summary of the unique secretory profiles observed in the different experimental groups. It appears that the multiplexed method of simultaneous immunoassay analysis is robust, as the profiles generally concurred well with the profiles determined by Western blot analysis. The observed mismatch in cytokines was probably due to differences either in sensitivities (CCL2, PDGFbb) or target epitopes (IL-1b and VEGF) between the two immunochemical methods. Furthermore, the three-dimensional primary culture model in conjunction with large-scale assays is a robust model system to study the endocrine, paracrine and juxtacrine aspects of the complex regulation of implantation-stage endometrial cells as suggested by other groups [30,31].

\section{Cell type specificity of secretory profiles under basal conditions}

Although CCL4, CCL5, CXCL9, CXCL12, FGF2, GMCSF, HGF, IL-2ra, IL-6, IL-12p40, MCSF, MIF and VEGF were observed to be consistently produced by all cells types, cell type specificity without the addition of hCG was evident. Endometrial epithelial cells showed a markedly different secretory profiles as compared with stromal cells; for example, the concentrations of CCL3, CCL7, CXCL1, CXCL10, IFNG, IL-1ra, IL-12p70, LIF, PDGFbb, and SCGF were much higher in the conditioned media of endometrial epithelial cells as compared with that of stromal cells, whereas the concentrations of CCL2 and IL-8 were much higher in the conditioned media of endometrial stromal cells as compared with that of epithelial cells. Clearly, epithelial cells secreted multiple cytokines.

As expected, there were marked similarities in the secretory profiles of most of the cytokines, chemokines and growth factors between homologous endometrial epithelial cells or stromal cells and heterologous mixed cells comprised of endometrial epithelial $(\approx 30 \%)$ plus stromal cells $(\approx 70 \%)$. However, two mediators showed differential profiles, GCSF and IL-9; although these factors were absent in the conditioned media of both endometrial epithelial cells and stromal cells, they were secreted in substantial amounts by mixed cells in heterologous culture. A high level of GCSF secretion only by 
A

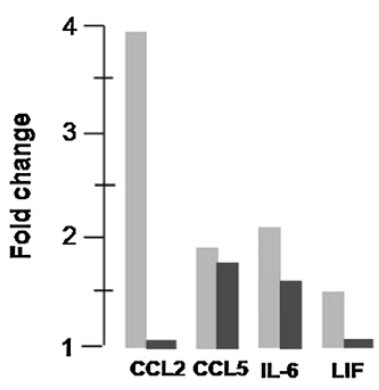

C

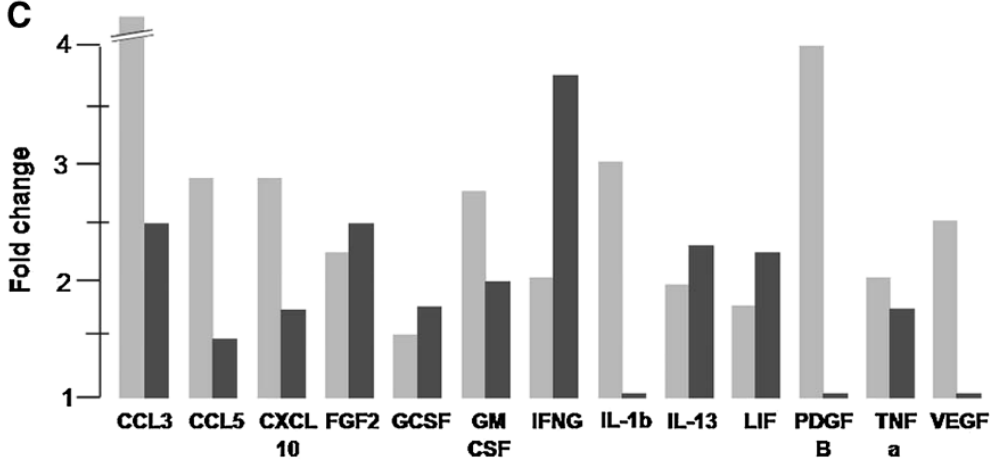

Figure 3 Bar diagram showing fold increase in protein and transcript levels from cells treated in vitro with and without hCG. Fold increase in protein levels between cultures treated without or with rhCG $(100 \mathrm{IU} / \mathrm{ml})$ in conditioned media (grey bar) and relative abundance of transcripts (black bar) in cultured (A) endometrial epithelial cells, (B) endometrial stromal cells, and (C) endometrial mixed cells are shown. The pattern of regulation by hCG depending on cell type and cytokine is evident. For example, the protein level of CCL2 is high but shows very little change at the transcript level, whereas levels of IL-6 at both the protein and transcript level are high following rhCG treatment only in epithelial cells (A). Similarly, the protein levels of FGF2 and GMCSF are high but show very little change at the transcript level in stromal cells (B), whereas both protein and transcript levels are high in the mixed cells $(\mathbf{C})$; these cytokines were unaffected in epithelial cells following hCG treatment. The pattern of changes in IFNG gene expression and protein secretion is very similar between endometrial stromal cells (B) and endometrial mixed cells (C) following administration of hCG.

mixed cells appears to be an interesting combinatorial paracrine function of the endometrium in view of the reported positive action of GCSF on endometrial stromal cells and growth for embryo implantation [32,33]. Many of the cytokines that were secreted by endometrial cells in basal culture conditions are known to be present in human endometrial cells and uterine fluid and directly and indirectly influence endometrial receptivity and embryo implantation [14,34-38].

\section{Cell type-specific differential responses to $\mathrm{hCG}$}

Many of the cytokines, chemokines and growth factors were differentially secreted in the medium following administration of recombinant hCG $(100 \mathrm{IU} / \mathrm{ml})$, especially from endometrial epithelial cells and mixed endometrial cells. It is notable that an hCG level of $100 \mathrm{IU} / \mathrm{ml}$ appears in the circulation during the first 7 weeks of pregnancy and that there is no allometric algorithm to determine the local level of hCG; thus, a significant modulatory effect of intraluminal administration of hCG could be recorded only at $500 \mathrm{IU} / \mathrm{ml}[10,39]$. Furthermore, the fact that there is a discernable difference in the cellular physiology of in vivo versus in vitro mammalian cells is well acknowledged $[19,22,23]$. Thus, we believe that the dosage for effective hCG $(100 \mathrm{IU} / \mathrm{ml})$ action may be specific to the in-vitro experimental model.

Many of the cytokines, chemokines and growth factors that were affected by hCG in the present study have also been reported to be influenced by hCG in the human endometrium in different experimental models as shown in Table 4. On the other hand, to our knowledge, this is the first report identifying the increased secretion of CCL3 (MIP-1a), CCL4 (MIP-1b), CCL5 (RANTES), IFNG, IL-13, PDGFbb and TRAIL and the decreased secretion of CCL7 (MCP-3), CXCL1 (GRO-a), CXCL9 (MIG), CXCL12 (SDF-1), HGF (SOS), IL-8, IL-16 and SCGF by mid-luteal phase endometrial cells following the in vitro administration of hCG. However, there are several reports indicating that many of these cytokines, 
Table 2 Summary of top scored features retrieved from reports of enrichment analysis from input list of cytokines, chemokines and growth factors showing high basal secretion and/or differential secretion following administration of hCG

\begin{tabular}{|c|c|c|c|}
\hline \multirow[t]{4}{*}{ Enrichment by } & \multicolumn{3}{|c|}{ Types of cell culture } \\
\hline & Epithelial cells & Stromal cells & Mixed cells \\
\hline & (Active products) & (Active products) & (Active products) \\
\hline & [pValue; FDR] & [pValue; FDR] & [pValue; FDR] \\
\hline \multirow[t]{6}{*}{ Pathway maps } & Immune response & Immune response & Immune response \\
\hline & $\begin{array}{c}\text { (CCL2, CCL4, CCL5, CCL7, XCL1, IL-6, } \\
\text { IL-12, HGF) }\end{array}$ & $\begin{array}{c}\text { (CCL4, GMCSF, IFNG, IL-1b, IL-6, IL-17, } \\
\text { MIF, VEGF) }\end{array}$ & $\begin{array}{l}\text { (CCL3, CCL4, CCL5, GCSF, GMCSF, HGF, } \\
\text { IFNG, IL-1b, IL-6, MIF, TNF, VEGF) }\end{array}$ \\
\hline & {$[8.3 \mathrm{E}-08 ; 1.6 \mathrm{E}-05]$} & [8.7E-08; 8.5E-06] & {$[1.9 \mathrm{E}-09 ; 4.3 \mathrm{E}-07]$} \\
\hline & Macropinocytotic transport & & Epithelial-mesenchymal transition \\
\hline & (HGF, MCSF) & & (FGF2, HGF, IL-1b, TNF) \\
\hline & {$[1.2 \mathrm{E}-05 ; 5.7 \mathrm{E}-04]$} & & [7.9E-05; 1.7E-05] \\
\hline \multirow[t]{9}{*}{ GO process } & Chemotaxis, leukocyte chemotaxis & Chemotaxis, leukocyte chemotaxis & $\begin{array}{l}\text { Regulation of response to stimulus, signal } \\
\text { transduction and cell communication }\end{array}$ \\
\hline & $\begin{array}{c}\text { (CCL2, CCL3, CCL4, CCL5, CCL7, CXCL1, } \\
\text { CXCL12, HGF, IL-6, MIF) }\end{array}$ & $\begin{array}{c}\text { (CCL4, IFNG, IL-1b, IL-6, IFNG, MIF, } \\
\text { VEGF) }\end{array}$ & $\begin{array}{l}\text { (CCL4, CCL5, CXCL12, FGF2, GCSF, GMCSF, } \\
\text { HGF, IL-13, LIF, MCSF, MIF, TNF, VEGF) }\end{array}$ \\
\hline & {$[9.9 \mathrm{E}-21 ; 7.9 \mathrm{E}-18]$} & {$[2.0 \mathrm{E}-15 ; 3.2 \mathrm{E}-12]$} & {$[1.8 \mathrm{E}-27 ; 3.7 \mathrm{E}-24]$} \\
\hline & & Regulation of response to stimulus & Chemotaxis, leukocyte chemotaxis \\
\hline & & (CCL4, FGF2, IL-1b, IL-6, IL-17 VEGF) & $\begin{array}{c}\text { (CCL3, CCL4, CCL5, CXCL12, FGF2, HGF, IFNG, } \\
\text { IL-1b, IL-6, MIF) }\end{array}$ \\
\hline & & {$[8.4 \mathrm{E}-14 ; 4.6 \mathrm{E}-11]$} & {$[5.2 \mathrm{E}-22 ; 2.8 \mathrm{E}-19]$} \\
\hline & & & Immune response \\
\hline & & & $\begin{array}{c}\text { (CCL3, CCL4, CCL5, CXCL9, CXCL10, GCSF, } \\
\text { MCSF, IFNG, IL-1b, IL-6, IL-13, LIF, MCSF, } \\
\text { MIF, TNF, VEGF) }\end{array}$ \\
\hline & & & {$[4.0 \mathrm{E}-21 ; 1.2 \mathrm{E}-18]$} \\
\hline \multirow{17}{*}{$\begin{array}{l}\text { Process } \\
\text { networks }\end{array}$} & Inflammation & Immune response & Inflammation \\
\hline & $\begin{array}{c}\text { (CCL2, CCL3, CCL4, CCL5, CCL7, CXCL12, } \\
\text { HGF, IL-6, IL-12, LIF, MCSF) }\end{array}$ & (GMCSF, IL-1b, IL-6, IL-17, MIF) & $\begin{array}{c}\text { (CCL3, CCL5, GCSF, GMCSF, IFNG, IL-6, IL-13, } \\
\text { LIF, MCSF, TNF) }\end{array}$ \\
\hline & {$[2.9 \mathrm{E}-09 ; 2.4 \mathrm{E}-07]$} & {$[4.9 E-09 ; 3.2 E-07]$} & {$[9.6 \mathrm{E}-13 ; 9.3 \mathrm{E}-11]$} \\
\hline & Chemotaxis & Signal transduction & \\
\hline & $\begin{array}{c}\text { (CCL2, CCL3, CCL4, CCL5, CCL7, CXCL1, } \\
\text { CXCL12) }\end{array}$ & (GMCSF, IFNG, IL-1b, VEGF) & \\
\hline & [5.7E-09; 2.4E-07] & {$[9.9 E-06 ; 3.1 E-04]$} & \\
\hline & Chemotaxis & Signal transduction & Proliferation \\
\hline & $\begin{array}{c}\text { (CCL2, CCL3, CCL4, CCL5, CCL7, CXCL1, } \\
\text { CXCL12) }\end{array}$ & (GMCSF, IFNG, IL-1b, VEGF) & (CXCL12, FGF2, GCSF, GMCSF, HGF, LIF, VEGF) \\
\hline & {$[5.7 \mathrm{E}-09 ; 2.4 \mathrm{E}-07]$} & [9.9E-06; 3.1E-04] & {$[6.6 \mathrm{E}-12 ; 3.2 \mathrm{E}-10]$} \\
\hline & Immune response & Inflammation & Cell adhesion \\
\hline & (CXCL12, CCL2, CXCL1, IL-6, CCL7, MIF) & (IL-1b, GMCSF, IFNG, CCL4, IL-6) & $\begin{array}{c}(\text { (IL-1b, TNF, CCL3, VEGF, MIF, FGF2, CCL5, } \\
\text { CCL4, CXCL12) }\end{array}$ \\
\hline & {$[1.5 \mathrm{E}-08 ; 2.4 \mathrm{E}-07]$} & {$[1.5 E-06 ; 3.1 E-04]$} & {$[3.3 \mathrm{E}-10 ; 1.1 \mathrm{E}-08]$} \\
\hline & Cell adhesion & Anti-apoptosis & Chemotaxis \\
\hline & $\begin{array}{c}\text { (CCL2, CCL3, CCL4, CCL5, CCL7, CXCL1, } \\
\text { CXCL12) }\end{array}$ & (FGF2, GMCSF, IL-1b, IL-6, VEGF) & $\begin{array}{c}\text { (CCL3, CCL4, CCL5, CXC12, FGF2, IL-1b, MIF, } \\
\text { VEGF) }\end{array}$ \\
\hline & {$[1.4 \mathrm{E}-08 ; 2.9 \mathrm{E}-06]$} & {$[2.3 E-05 ; 3.7 E-04]$} & {$[9.4 \mathrm{E}-10 ; 2.3 \mathrm{E}-08]$} \\
\hline & Proliferation & Cell adhesion & Anti-apoptosis \\
\hline & (CCL4, CCL5, CXCL12, HGF, IL-12) & (FGF2, IL-1b, IL-6, VEGF) & $\begin{array}{c}\text { (CCL3, FGF2, GMCSF, HGF, IL-1b, IL-6, } \\
\text { TNF, VEGF) }\end{array}$ \\
\hline
\end{tabular}


Table 2 Summary of top scored features retrieved from reports of enrichment analysis from input list of cytokines, chemokines and growth factors showing high basal secretion and/or differential secretion following administration of hCG (Continued)

[2.4E-07; 4.1E-06]
$[1.4 \mathrm{E}-04 ; 1.0 \mathrm{E}-03]$
[5.8E-09; 9.4E-08]

Immune response

(GCSF, GMCSF, IL-1b, IL-6, MIF)

[5.2E-08; 6.3E-07]

FDR false discovery rate.

chemokines and growth factors in implantation-stage endometrium may be regulated by various paracrine mediators, such as INFG, IL-1, IL-6, PAF, thrombin and TNF, which are potentially secreted from implantation-stage endometrium and the embryo [40-52]. We observed that hCG could influence the secretion of many of these paracrine mediators (INFG, IL-1b, IL-6, and TNF) by implantation-stage endometrium. Furthermore, some of the cytokines, chemokines and growth factors (CCL3, CCL4, CCL5, FGF2, GCSF, GMCSF, IL-1b, IL-6, IL-8, LIF, PDGFbb, TNF and VEGF) that were found to be differentially regulated by hCG in endometrial cells are known to have direct or indirect action in supporting embryo implantation [33,53-55], and indeed a few (CCL2, CXCL10, IL-1b and TNF) have shown significant correlation with successful implantation and establishment of clinical pregnancy [56].

\section{CG may control the endometrial informational networks} that promote receptivity

The results obtained in the present study strongly corroborate the notion that hCG influences the physiology of the endometrium and embryo during the time of blastocyst implantation. Based on a large number of previous reports [21,32-80], we have constructed a tentative model of the hCG-mediated paracrine activity controlling implantation of the embryo and the endometrium (Figure 4). It is apparent that several embryotropic cytokines, chemokines and growth factors, which include CCL3, CCL4, CCL5, CXCL10, FGF2, GMCSF, IFNG, IL1b, IL-6, IL-13, LIF, PDGF, TNF and VEGF, were upregulated in implantation-stage endometrium by hCG. Furthermore, several of these cytokines are known to regulate stromal fibroblasts (e.g., FGF2, GCSF, GMCSF, IFNG, IL-1b, IL-6, LIF, MIF, TNF and TRAIL), vascular physiology (e.g., CCL2, CXCL10, GMCSF, IL-1b, IL-6, LIF, MIF, PDGFbb, TNF and VEGF) and glandular physiology (e.g., LIF, MIF, PDGFbb, and TNF). Many of these factors directly and indirectly regulate the function of immunocompetent cells. Thus, CG may affect endometrial functions related to inflammation, differentiation, proliferation, apoptosis, immune surveillance and immune tolerance through the production of a set of

Table 3 Summary of the major observations from the present study

\begin{tabular}{|c|c|c|}
\hline (Description) Group & $\begin{array}{l}\text { Concentration level of secretion } \\
\text { (pg in } \mu \mathrm{g} \text { protein) in basal condition }\end{array}$ & $\begin{array}{c}\text { Name of cytokines showing differential }{ }^{1} \text { secretion following } \\
\text { administration of } \text { hCG }^{-}\end{array}$ \\
\hline Group 1 & $\leq 1$ & $\operatorname{CCL2}(+)$, TRAIL $(+)$ \\
\hline \multirow[t]{3}{*}{ (Endometrial epithelial cells) } & $>1-10$ & $\operatorname{CCL5}(+), \operatorname{CCL7}(-), \operatorname{CXCL12}(-), \operatorname{HGF}(-)$, IL-12p40 (-), LIF (+), MCSF (-) \\
\hline & $>10-100$ & CCL4 (+), CXCL1 $(-)$, MIF $(+)$, SCGF $(-)$ \\
\hline & $>100$ & IL-6 (+) \\
\hline Group 2 & $\leq 1$ & $\operatorname{IL} 1 \mathrm{~b}(+), \operatorname{IL}-16(-), \operatorname{IL} 17(+)$ \\
\hline \multirow[t]{4}{*}{ (Endometrial stromal cells) } & & $\operatorname{CCL} 4(+)$, FGF2 (+), IFNG (+), IL-6 (-), VEGF (+) \\
\hline & $>1-10$ & $\operatorname{GMCSF}(+), \operatorname{MIF}(-)$ \\
\hline & $>10-100$ & None \\
\hline & $>100$ & \\
\hline Group 3 & $\leq 1$ & $\begin{array}{c}\operatorname{CCL3}(+), \operatorname{CXCL10}(+), \operatorname{IL}-1 \mathrm{~b}(+), \operatorname{IL}-12 \text { p70 }(+), \text { IL-13 }(+), \operatorname{IL}-16(-), \operatorname{LIF}(+), \\
\operatorname{PDGFbb}(+), \operatorname{TNF}(+), \operatorname{TRAIL}(-)\end{array}$ \\
\hline \multirow[t]{3}{*}{ (Endometrial mixed cells) } & $>1-10$ & $\operatorname{CCL4}(+), \operatorname{CCL} 5(+), \operatorname{CXCL9}(-), \operatorname{FGF} 2(+), \operatorname{GMCSF}(+), \operatorname{HGF}(-), \operatorname{IFNG}(+), \operatorname{MCSF}(-)$ \\
\hline & $>10-100$ & $\operatorname{GCSF}(+), \mathbf{I L}-\mathbf{8}(-), \operatorname{MIF}(-), \operatorname{VEGF}(+)$ \\
\hline & $>100$ & IL-6 (-) \\
\hline
\end{tabular}

(+), up-regulated. (-), down-regulated.

The cytokines, chemokines and growth factors which were regulated in cell culture group specific manner are shown in bold.

${ }^{1} \geq 1.5$-fold at $\mathrm{P}<0.05$. 
Table 4 A summary of the results from the present study and previous reports for common endometrial secretions observed to be affected by hCG

\begin{tabular}{|c|c|c|c|}
\hline Name & $\begin{array}{l}\text { Observation in the present } \\
\text { study; affected cell culture } \\
\text { type }\end{array}$ & $\begin{array}{l}\text { Observation in the previous } \\
\text { studies; experimental model } \\
\text { [Reference] }\end{array}$ & Putative function in implantation process [Reference] \\
\hline CCL2 & Increase: epithelial HEnC & $\begin{array}{l}\text { No change; mixed endometrial cells }{ }^{1} \\
{[45]}\end{array}$ & $\begin{array}{l}\text { Regulation of angiogenic and immunotolerant environment } \\
\qquad[57,58]\end{array}$ \\
\hline CXCL10 & Increase; mixed HEnC & Increase; HEEC ${ }^{1}$ [14] & Regulation of NK cell recruitment and angiogenesis $[59,60]$ \\
\hline FGF2 & $\begin{array}{l}\text { Increase; stromal HEnC and } \\
\text { mixed HEnC }\end{array}$ & Increase; HEEC ${ }^{1}[14]$ & $\begin{array}{l}\text { Regulates endometrial stromal cell proliferation and receptivity } \\
\text { and embryo growth, attachment and trophoblast function } \\
\qquad[61,62]\end{array}$ \\
\hline GMCSF & $\begin{array}{l}\text { Increase; stromal HEnC and } \\
\text { mixed HEnC }\end{array}$ & Increase; HEEC ${ }^{1}[14]$ & $\begin{array}{c}\text { Regulates endometrial stromal cells, leukocytes and capillaries } \\
\text { along with embryotropic action }[34,53,63]\end{array}$ \\
\hline \multirow[t]{3}{*}{$\mathrm{IL}-1 \mathrm{~b}$} & \multirow{3}{*}{$\begin{array}{l}\text { Increase; stromal HEnC and } \\
\text { mixed HEnC }\end{array}$} & Increase; intrauterine secretion ${ }^{2}$ [39] & \multirow[t]{3}{*}{ Mediates endometrial preparation for implantation $[36,58]$} \\
\hline & & $\begin{array}{l}\text { No change; mixed endometrial cells }{ }^{1} \\
{[45]}\end{array}$ & \\
\hline & & $\begin{array}{l}\text { Increase; endometrial secretion } \\
\text { aspiration }{ }^{3}[64]\end{array}$ & \\
\hline \multirow[t]{4}{*}{ IL-6 } & \multirow{4}{*}{$\begin{array}{c}\text { Increase; epithelial HEnC } \\
\text { Decrease; stromal HEnC and } \\
\text { mixed HEnC }\end{array}$} & Increase; intrauterine secretion ${ }^{2}$ [39] & \multirow{4}{*}{$\begin{array}{r}\text { Regulates hCG secretion by trophoblast cells and endometrial } \\
\text { development }[36,65,66]\end{array}$} \\
\hline & & $\begin{array}{c}\text { Increase; mixed endometrial cells }{ }^{1} \\
{[67]}\end{array}$ & \\
\hline & & Decrease; HEEC $[7]$ & \\
\hline & & No change; HEEC ${ }^{1}[14]$ & \\
\hline \multirow[t]{2}{*}{$\mid \mathrm{L}-12$} & Decrease (p40); epithelial HEnC & Endometrial secretion aspiration ${ }^{3}[64]$ & \multirow{2}{*}{$\begin{array}{l}\text { Regulates NK cell function and mediates cell mediated immunity } \\
{[68]}\end{array}$} \\
\hline & Increase (p70); mixed HEnC & & \\
\hline IL-17 & Increase; stromal HEnC & $\begin{array}{l}\text { Increase; endometrial secretion } \\
\text { aspiration }{ }^{3}[64]\end{array}$ & Potentially regulates chemokines and cytokines networks [69] \\
\hline \multirow[t]{3}{*}{ LIF } & \multirow[t]{3}{*}{$\begin{array}{l}\text { Increase; epithelial HEnC and } \\
\text { mixed HEnC }\end{array}$} & $\begin{array}{l}\text { No change; mixed endometrial cells }{ }^{1} \\
{[67]}\end{array}$ & \multirow[t]{3}{*}{ Supports endometrial receptivity and embryo development [36] } \\
\hline & & Increase; intrauterine secretion ${ }^{2}[39]$ & \\
\hline & & Increase; HEEC $[7,14]$ & \\
\hline MCSF & $\begin{array}{l}\text { Decrease; epithelial HEnC and } \\
\text { mixed HEnC }\end{array}$ & Decrease; intrauterine secretion ${ }^{2}$ [39] & $\begin{array}{c}\text { Paracrine regulation of stromal decidualization under } \\
\text { progesterone dominance }[70,71]\end{array}$ \\
\hline \multirow[t]{2}{*}{ MIF } & $\begin{array}{l}\text { Increase; epithelial HEnC and } \\
\text { mixed HEnC }\end{array}$ & Increase; endomerial stromal cells ${ }^{1}[9]$ & $\begin{array}{l}\text { Paracrine regulation of immunomodulation, angiogenesis and } \\
\text { growth }[47,72]\end{array}$ \\
\hline & Decrease; stromal HEnC & & \\
\hline \multirow[t]{2}{*}{ TNF } & Increase; mixed HEnC & $\begin{array}{c}\text { Increase; mixed endometrial cells }{ }^{1} \\
{[64]}\end{array}$ & \multirow[t]{2}{*}{$\begin{array}{l}\text { Regulates balance of cytokine, chemokines and growth factors } \\
\text { towards endometrial and embryo development }[73,74]\end{array}$} \\
\hline & & $\begin{array}{l}\text { Increase; endometrial secretion } \\
\qquad \text { aspiration }^{3}[39]\end{array}$ & \\
\hline \multirow[t]{4}{*}{ VEGF } & \multirow{4}{*}{$\begin{array}{l}\text { Increase; stromal HEnC and } \\
\text { mixed HEnC }\end{array}$} & Increase; intrauterine secretion ${ }^{2}[39]$ & \multirow{4}{*}{$\begin{array}{l}\text { Regulates endometrial angiogenesis, permeability receptivity anc } \\
\qquad \text { embryo development }[36,75,76]\end{array}$} \\
\hline & & Increase; HEEC $[7,14,77]$ & \\
\hline & & $\begin{array}{c}\text { Increase; mixed endometrial cells }{ }^{1} \\
{[78]}\end{array}$ & \\
\hline & & Increase; epithelial HEnC [25] & \\
\hline
\end{tabular}

HEnC, endometrial cells in primary culture on collagen biomatrix. HEEC, isolated human endometrial epithelial cells. HEExC, human endometrial explant culture. ${ }^{1}$ Conventional primary culture.

${ }^{2}$ Intrauterine microdialysis. ${ }^{3}$ endometrial secretion aspired on the day of embryo transfer in stimulated cycle in IVF-ET and compared with that in natural cycle.

cytokines, chemokines and growth factors during the time of blastocyst implantation. Additionally, hCG influences macropinocytic transport in epithelial cells, regulates responses to external stimuli in stromal cells and promotes epithelial-mesenchymal transition in mixed cells. These are well-known biological features of implantation-stage endometrial tissue [79]. Further networks analysis in determining the hierarchy of different functional processes revealed that the regulation of inflammation, proliferation, cell adhesion, chemotaxis, apoptosis and immune response 

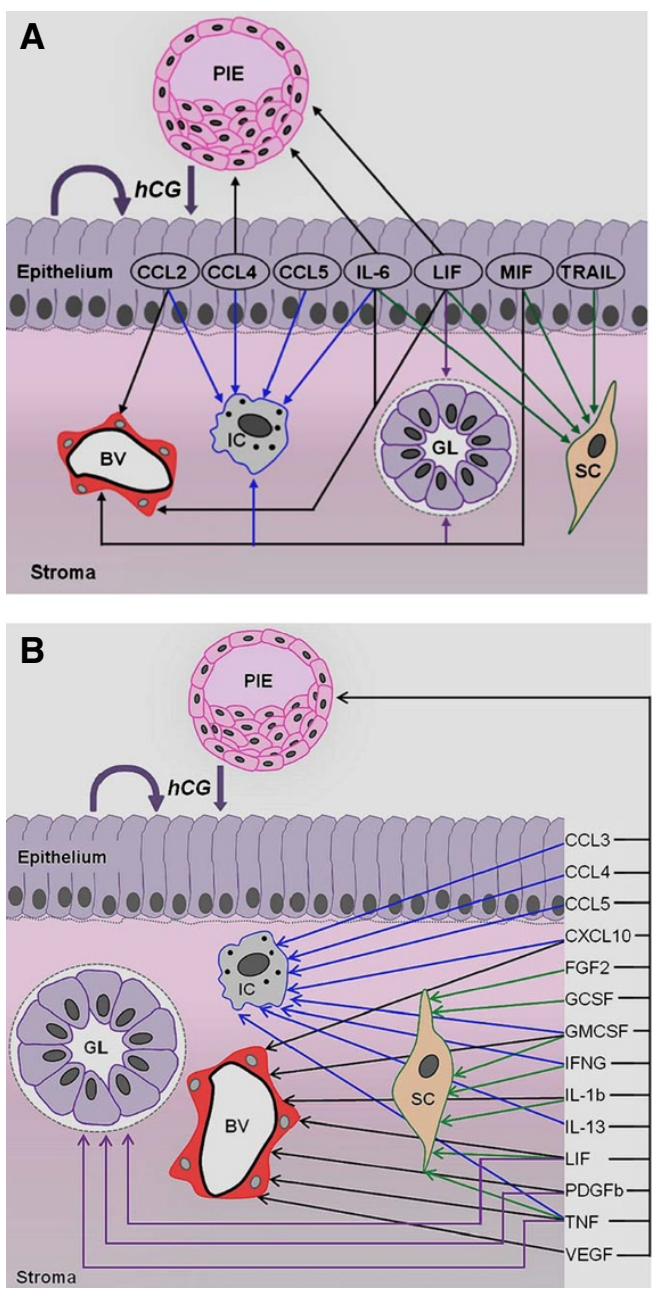

Figure $4 \mathrm{~A}$ proposed model of the paracrine action mediated by hCG that involves different cell types in the endometrium and that affects the implantation-stage embryo and endometrium. The pre-implantation embryo- and endometrium-derived CG may specifically act on endometrial surface epithelium alone (A) or may act on both the endometrial epithelial cells and stromal fibroblasts (B), resulting in up-regulation of a specific cohort of cytokines, chemokines and growth factors. Many of these factors (e.g., CCL3, CCL4, CCL5, CXCL10, FGF2, GMCSF, IFNG, IL-1b, IL-6, IL-13, LIF, PDGFb, TNF and VEGF) are reportedly embryotropic, some (e.g., IL-6 and LIF) are primarily secreted by endometrial epithelial cells, and a few (e.g., FGF2, GMCSF, INFG, IL-1b and VEGF) are secreted primarily by endometrial fibroblasts in response to hCG. In contrast, many of the secreted factors are known to regulate stromal fibroblasts (e.g., FGF2, GCSF, GMCSF, IFNG, IL-1b, IL-6, LIF, MIF, TNF and TRAIL), vasCular physiology (e.g., CCL2, CXCL10, GMCSF, IL-1b, IL-6, LIF, MIF, PDGFb, TNF and VEGF) and glandular physiology (e.g., LIF, MIF, PDGFb, and TNF). Only a few of the factors (e.g., CCL2, IL-6, LIF and MIF) are secreted by isolated endometrial epithelial cells in response to hCG. Interestingly, many of these factors directly and indirectly regulate the functions of immunocompetent cells. A large number of reports $[21,32-53,57-78,80]$ and the results of the present study have been used to develop this model. BV (blood vessel), FB (fibroblast), GL (gland), IC (immunocompetent cells), PIE (pre-implantation embryo). There is no quantitative aspect to the length and thickness of arrows. are the dominant actions of hCG on implantation-stage endometrium.

In general, administration of CG can influence the function of the endometrium during embryo implantation. There are at least three aspects of CG-regulated endometrial informational networks that may further be examined to elucidate its potential involvement in the implantation process. First, studies are required to understand the mechanism by which CG regulates the above-mentioned physiological modules, namely inflammation, proliferation, cell adhesion, chemotaxis, apoptosis and immune response, on the background of progesterone dominance in endometrial cells during implantation. Secondly, further studies are necessary to unravel how CG could exert differential effects on transcript and protein levels at the steady state depending on cell type and cytokine as revealed in the present study. A large number of reports indicate that manifestation of such poor correlations suggests multi-level regulation by an input signal [81-84], which was hCG in this study. Thirdly, additional multi-scale and multi-level studies are necessary to understand the CG-mediated regulation of endometrial functions at implantation that involve paracrine control between cell types.

\section{Conclusions}

Several interesting points may be concluded from the results of the present study. First, the primary cell culture of human endometrial cells on collagen biomatrix is a robust experimental model to study the endocrine, paracrine and juxtacrine actions of a biological molecule, hCG. Despite the fact that there were several cytokines, chemokines and growth factors commonly secreted by isolated endometrial epithelial cells, stromal cells and mixed cells under basal conditions, there were many cytokines that were secreted specifically by endometrial epithelial cells. However, a substantial level of GCSF was produced by endometrial cells only when epithelial and stromal cellular elements were mutually interactive. Thus, GCSF appears to be a potential physiological marker of the functional integrity of the endometrium. Furthermore, it was demonstrated for the first time that administration of hCG could affect isolated endometrial epithelial cells, stromal cells and mixed cells in a differential fashion. Many of the factors are known to exert paracrine influence on implantation-stage endometrium (e.g., IFNG, IL-1b, IL-6 and TNF) and support embryo implantation (e.g., CCL3, CCL4, CCL5, FGF2, GCSF, IL-1b, IL-6, IL-8, LIF, PDGFbb, TNF and VEGF) through their regulatory actions on inflammation, proliferation, cell adhesion, chemotaxis, apoptosis and immune responses during blastocyst implantation. It is thus apparent that embryo- and endometrial-derived CG can influence implantation-stage endometrial functions through complex 
processes involving various cell types in the endometrium. Finally, this study provided a panel of specific cytokines, chemokines and growth factors that are secreted by various cell types in the endometrium during the window of implantation.

\section{Additional files}

Additional file 1: Table S1. Cytokines, chemokines and growth factors studied.

Additional file 2: Table S2. Primary antibodies used in the study.

Additional file 3: Table S3. List of genes and their primers used for quantitative real time RT-PCR.

Additional file 4: Table S4. Profiles of secreted cytokines, chemokines and growth factors from isolated endometrial cells of three culture groups in the basal condition.

\section{Competing interests}

The authors declare that they have no competing interests.

\section{Authors' contributions}

AKS contributed in performing experiments, data acquisition and data analysis. JS and DG contributed to the study design, acquisition, analysis and interpretation of data, and drafting of the manuscript. AK and KKR contributed in providing human samples and data interpretation. All authors read and approved the final manuscript.

\section{Acknowledgements}

The authors acknowledge the support of the Molecular Biology Laboratory and the Confocal Imaging Facility of the Department of Physiology, All India Institute of Medical Sciences. The authors thank Mr Harpal Rana for his support in the imaging procedures. The study was supported by the Department of Science and Technology, Government of India (Grant number D-244). The authors also acknowledge the support from the language editing service from Elsewier Language Editing. The authors are thankful to the reviewers for their critical and constructive comments and suggestions on the manuscript.

\section{Author details}

'Department of Physiology, All India Institute of Medical Sciences, New Delhi, India. ${ }^{2}$ Department of Obstetrics and Gynaecology, All India Institute of Medical Sciences, New Delhi, India. ${ }^{3}$ Present address: Department of Physiology, North DMC Medical College, Hindu Rao Hospital, New Delhi 110007, India.

Received: 28 June 2013 Accepted: 10 December 2013

Published: 17 December 2013

\section{References}

1. Banerjee P, Fazleabas AT: Endometrial responses to embryonic signals in the primate. Int J Dev Biol 2010, 54:295-302.

2. Fishel SB, Edwards RG, Evans CJ: Human chorionic gonadotropin secreted by preimplantation embryos cultured in vitro. Science 1984, 223:816-818.

3. Jurisicova A, Antenos M, Kapasi K, Meriano J, Casper RF: Variability in the expression of trophectodermal markers beta-human chorionic gonadotrophin, human leukocyte antigen- $G$ and pregnancy specific beta-1 glycoprotein by the human blastocyst. Hum Reprod 1999, 14:1852-1858.

4. Zimmermann G, Ackermann W, Alexander H: Epithelial human chorionic gonadotropin is expressed and produced in human secretory endometrium during the normal menstrual cycle. Biol Reprod 2009, 80:1053-1065.

5. Zimmermann G, Ackermann W, Alexander H: Expression and production of human chorionic gonadotropin (hCG) in the normal secretory endometrium: evidence of CGB7 and/or CGB6 beta hCG subunit gene expression. Biol Reprod 2012, 86:87.

6. Licht P, von Wolff M, Berkholz A, Wildt L: Evidence for cycle-dependent expression of full-length human chorionic gonadotropin/luteinizing hormone receptor mRNA in human endometrium and decidua. Fertil Steril 2003, 79(Suppl 1):718-723.

7. Perrier d'Hauterive S, Charlet-Renard C, Berndt S, Dubois M, Munaut C, Goffin F, Hagelstein MT, Noël A, Hazout A, Foidart JM, Geenen V: Human chorionic gonadotropin and growth factors at the embryonic-endometrial interface control leukemia inhibitory factor (LIF) and interleukin 6 (IL-6) secretion by human endometrial epithelium. Hum Reprod 2004, 19:2633-2643.

8. Fazleabas AT, Donnelly KM, Srinivasan S, Fortman JD, Miller JB: Modulation of the baboon (Papio anubis) uterine endometrium by chorionic gonadotrophin during the period of uterine receptivity. Proc Natl Acad Sci U S A 1999, 96:2543-2548.

9. Akoum A, Metz CN, Morin M: Marked increase in macrophage migration inhibitory factor synthesis and secretion in human endometrial cells in response to human chorionic gonadotropin hormone. J Clin Endocrinol Metab 2005, 90:2904-2910.

10. Licht P, Russu V, Wildt L: On the role of human chorionic gonadotropin (hCG) in the embryo-endometrial microenvironment: implications for differentiation and implantation. Semin Reprod Med 2001, 19:37-47.

11. Fluhr H, Bischof-Islami D, Krenzer S, Licht P, Bischof P, Zygmunt M: Human chorionic gonadotropin stimulates matrix metalloproteinases-2 and -9 in cytotrophoblastic cells and decreases tissue inhibitor of metalloproteinases-1, -2 , and -3 in decidualized endometrial stromal cells. Fertil Steril 2008, 90(Suppl 4):1390-1395.

12. Sherwin JR, Sharkey AM, Cameo P, Mavrogianis PM, Catalano RD, Edassery S, Fazleabas AT: Identification of novel genes regulated by chorionic gonadotropin in baboon endometrium during the window of implantation. Endocrinology 2007, 148:618-626.

13. Fogle RH, Li A, Paulson RJ: Modulation of HOXA10 and other markers of endometrial receptivity by age and human chorionic gonadotropin in an endometrial explant model. Fertil Steril 2010, 93:1255-1259.

14. Paiva P, Hannan NJ, Hincks C, Meehan KL, Pruysers E, Dimitriadis E, Salamonsen LA: Human chorionic gonadotrophin regulates FGF2 and other cytokines produced by human endometrial epithelial cells, providing a mechanism for enhancing endometrial receptivity. Hum Reprod 2011, 26:1153-1162.

15. Kajihara T, Uchino S, Suzuki M, Itakura A, Brosens JJ, Ishihara O: Human chorionic gonadotropin confers resistance to oxidative stress-induced apoptosis in decidualizing human endometrial stromal cells. Fertil Steril 2011, 95:1302-1307.

16. Kajihara T, Tochigi H, Uchino S, Itakura A, Brosens JJ, Ishihara O: Differential effects of urinary and recombinant chorionic gonadotropin on oxidative stress responses in decidualizing human endometrial stromal cells. Placenta 2011, 32:592-597.

17. Fluhr H, Ramp K, Krenzer S, Licht P, Zygmunt M: Inverse regulation of the interferon-gamma receptor and its signaling in human endometrial stromal cells during decidualization. Fertil Steril 2009, 91(Suppl 5):2131-2136.

18. Bentin-Ley U, Pedersen B, Lindenberg S, Larsen JF, Hamberger L, Horn T: Isolation and culture of human endometrial cells in a three-dimensional culture system. J Reprod Fertil 1994, 101:327-332.

19. Ghosh D, Sengupta J: Morphological characteristics of human endometrial epithelial cells cultured on rat-tail collagen matrix. Hum Reprod 1995, 10:785-790.

20. Evron A, Goldman S, Shalev E: Effect of primary human endometrial stromal cells on epithelial cell receptivity and protein expression is dependent on menstrual cycle stage. Hum Reprod 2011, 26:176-190.

21. COPE Cytokines \& Cells Online Pathfinder Encyclopediaversion 31.4. http:// www.copewithcytokines.de/cope.cgi?key=endometrial\%20cells].

22. Ghosh D, Danielson KG, Alston JT, Heyner S: Functional differentiation of mouse uterine epithelial cells grown on collagen gels or reconstituted basement membranes. In Vitro Cell Dev Biol 1991, 27:713-719.

23. Sengupta J, Given RL, Carey JB, Weitlauf HM: Primary culture of mouse endometrium on floating collagen gels: a potential in vitro model for implantation. Ann N Y Acad Sci 1986, 476:75-94.

24. Sengupta J, Khan MA, Huppertz B, Ghosh D: In-vitro effects of the antimicrobial peptide Ala8,13,18-magainin II amide on isolated human first trimester villous trophoblast cells. Reprod Biol Endocrinol 2011, 9:49.

25. Sengupta S, Sengupta J, Mittal S, Kumar S, Ghosh D: Effect of human chorionic gonadotropin ( $\mathrm{hCG}$ ) on expression of vascular endothelial growth factor a (VEGF-a) in human mid-secretory endometrial cells in three-dimensional primary culture. Indian J Physiol Pharmacol 2008, 52:19-30. 
26. de Jager W, Rijkers GT: Solid-phase and bead-based cytokine immunoassay: a comparison. Methods 2006, 38:294-303.

27. Khan MA, Sengupta J, Mittal S, Ghosh D: Genome-wide expressions in autologous eutopic and ectopic endometrium of fertile women with endometriosis. Reprod Biol Endocrinol 2012, 10:84.

28. Schroeder A, Mueller O, Stocker S, Salowsky R, Leiber M, Gassmann M, Lightfoot S, Menzel W, Granzow M, Ragg T: The RIN: an RNA integrity number for assigning integrity values to RNA measurements. BMC Mol Biol 2006, 7:3.

29. MetaCorebio manual 5.0. https://portal.genego.com/help/ MetaCore_bio_manual_5.

30. Bentin-Ley U, Lopata A: In vitro models of human blastocyst implantation. Baillieres Best Pract Res Clin Obstet Gynaecol 2000, 14:765-774.

31. Lalitkumar PG, Lalitkumar S, Meng CX, Stavreus-Evers A, Hambiliki F, Bentin-Ley U, Gemzell-Danielsson K: Mifepristone, but not levonorgestrel, inhibits human blastocyst attachment to an in vitro endometrial three-dimensional cell culture model. Hum Reprod 2007, 22:3031-3037.

32. Tanaka T, Miyama M, Masuda M, Mizuno K, Sakamoto T, Umesaki N, Ogita S: Production and physiological function of granulocyte colony-stimulating factor in non-pregnant human endometrial stromal cells. Gynecol Endocrinol 2000, 14:399-404.

33. Gleicher N, Vidali A, Barad DH: Successful treatment of unresponsive thin endometrium. Fertil Steril 2011, 95:2123.e13-2123.e17.

34. Dimitriadis E, White CA, Jones RL, Salamonsen LA: Cytokines, chemokines and growth factors in endometrium related to implantation. Hum Reprod Update 2005, 11:613-630.

35. Fahey JV, Schaefer TM, Channon JY, Wira CR: Secretion of cytokines and chemokines by polarized human epithelial cells from the female reproductive tract. Hum Reprod 2005, 20:1439-1446.

36. Guzeloglu-Kayisli O, Kayisli UA, Taylor HS: The role of growth factors and cytokines during implantation: endocrine and paracrine interactions. Semin Reprod Med 2009, 27:62-79.

37. Hannan NJ, Stoikos CJ, Stephens AN, Salamonsen LA: Depletion of high-abundance serum proteins from human uterine lavages enhances detection of lower-abundance proteins. J Proteome Res 2009, 8:1099-1103.

38. Boomsma CM, Kavelaars A, Eijkemans MJ, Amarouchi K, Teklenburg G, Gutknecht D, Fauser BJ, Heijnen CJ, Macklon NS: Cytokine profiling in endometrial secretions: a non-invasive window on endometrial receptivity. Reprod Biomed Online 2009, 18:85-94.

39. Licht $P$, Lösch A, Dittrich $R$, Neuwinger J, Siebzehnrübl E, Wildt L: Novel insights into human endometrial paracrinology and embryo-maternal communication by intrauterine microdialysis. Hum Reprod Update 1998, 4:532-538.

40. Nasu K, Matsui N, Narahara H, Tanaka Y, Miyakawa I: Effects of interferon-gamma on cytokine production by endometrial stromal cells. Hum Reprod 1998, 13:2598-2601.

41. Nasu K, Narahara H, Matsui N, Kawano Y, Tanaka Y, Miyakawa I: Platelet-activating factor stimulates cytokine production by human endometrial stromal cells. Mol Hum Reprod 1999, 5:548-553.

42. Lebovic DI, Chao VA, Martini JF, Taylor RN: IL-1 beta induction of RANTES (regulated upon activation, normal T cell expressed and secreted) chemokine gene expression in endometriotic stromal cells depends on a nuclear factor-kappaB site in the proximal promoter. J Clin Endocrinol Metab 2001, 86:4759-4764.

43. Akoum A, Kong J, Metz C, Beaumont MC: Spontaneous and stimulated secretion of monocyte chemotactic protein-1 and macrophage migration inhibitory factor by peritoneal macrophages in women with and without endometriosis. Fertil Steril 2002, 77:989-994.

44. Caballero-Campo P, Domínguez F, Coloma J, Meseguer M, Remohí J, Pellicer A, Simón C: Hormonal and embryonic regulation of chemokines IL-8, MCP-1 and RANTES in the human endometrium during the window of implantation. Mol Hum Reprod 2002, 8:375-384.

45. Kang J, Akoum A, Chapdelaine P, Laberge P, Poubelle PE, Fortier MA: Independent regulation of prostaglandins and monocyte chemoattractant protein-1 by interleukin-1 beta and hCG in human endometrial cells. Hum Reprod 2004, 19:2465-2473.

46. Cao WG, Morin M, Metz C, Maheux R, Akoum A: Stimulation of macrophage migration inhibitory factor expression in endometrial stromal cells by interleukin 1, beta involving the nuclear transcription factor NF-kappaB. Biol Reprod 2005, 73:565-570.
47. Cao WG, Morin M, Sengers $V$, Metz C, Roger $T$, Maheux R, Akoum A: Tumour necrosis factor-alpha up-regulates macrophage migration inhibitory factor expression in endometrial stromal cells via the nuclear transcription factor NF-kappaB. Hum Reprod 2006, 21:421-428.

48. Khan KN, Masuzaki H, Fujishita A, Kitajima M, Hiraki K, Sekine I, Matsuyama T, Ishimaru T: Interleukin-6- and tumour necrosis factor alpha-mediated expression of hepatocyte growth factor by stromal cells and its involvement in the growth of endometriosis. Hum Reprod 2005, 20:2715-2723

49. Roberts M, Luo X, Chegini N: Differential regulation of interleukins IL-13 and IL-15 by ovarian steroids, TNF-alpha and TGF-beta in human endometrial epithelial and stromal cells. Mol Hum Reprod 2005, 11:751-760.

50. Kitaya K, Yasuo T, Yamaguchi T, Fushiki S, Honjo H: Genes regulated by interferon-gamma in human uterine microvascular endothelial cells. Int J Mol Med 2007, 20:689-697.

51. Kawano Y, Fukuda J, Nasu K, Matsumoto H, Narahara H, Miyakawa I: Synergistic effect of interleukin (IL)-1alpha and ceramide analogue on the production of IL-6, IL-8, and macrophage colony-stimulating factor by endometrial stromal cells. Fertil Steril 2004, 82(Suppl 3):1043-1047.

52. Kawano Y, Furukawa Y, Kawano Y, Nasu K, Narahara H: Thrombin-induced chemokine production in endometrial stromal cells. Hum Reprod 2011, 26:407-413

53. Robertson SA, Seamark RF: Granulocyte-macrophage colony stimulating factor (GM-CSF): one of a family of epithelial cell-derived cytokines in the preimplantation uterus. Reprod Fertil Dev 1992, 4:435-448.

54. Ishiwata I, Tokieda Y, Kiguchi K, Sato K, Ishikawa H: Effects of embryotrophic factors on the embryogenesis and organogenesis of mouse embryos in vitro. Hum Cell 2000, 13:185-195.

55. Orsi NM, Ekbote UV, Walker JJ, Gopichandran N: Uterine and serum cytokine arrays in the mouse during estrus. Anim Reprod Sci 2007, 100:301-310.

56. Boomsma CM, Kavelaars A, Eijkemans MJ, Lentjes EG, Fauser BC, Heijnen CJ, Macklon NS: Endometrial secretion analysis identifies a cytokine profile predictive of pregnancy in IVF. Hum Reprod 2009, 24:1427-1435.

57. Bourdiec A, Shao R, Rao CV, Akoum A: Human chorionic gonadotropin triggers angiogenesis via the modulation of endometrial stromal cell responsiveness to interleukin 1: a new possible mechanism underlying embryo implantation. Biol Reprod 2012, 87:66.

58. Selam B, Kayisli UA, Akbas GE, Basar M, Arici A: Regulation of FAS ligand expression by chemokine ligand 2 in human endometrial cells. Biol Reprod 2006, 75:203-209.

59. Kitaya K, Nakayama T, Daikoku N, Fushiki S, Honjo H: Spatial and temporal expression of ligands for CXCR3 and CXCR4 in human endometrium. J Clin Endocrinol Metab 2004, 89:2470-2476.

60. Rainczuk A, Rao J, Gathercole J, Stephens AN: The emerging role of CXC chemokines in epithelial ovarian cancer. Reproduction 2012, 144:303-317.

61. Möller B, Rasmussen C, Lindblom B, Olovsson M: Expression of the angiogenic growth factors VEGF, FGF-2, EGF and their receptors in normal human endometrium during the menstrual cycle. Mol Hum Reprod 2001, 7:65-72

62. Chan RW, Schwab KE, Gargett CE: Clonogenicity of human endometrial epithelial and stromal cells. Biol Reprod 2004, 70:1738-1750.

63. Sjöblom C, Roberts CT, Wikland M, Robertson SA: Granulocyte-macrophage colony-stimulating factor alleviates adverse consequences of embryo culture on fetal growth trajectory and placental morphogenesis. Endocrinology 2005, 146:2142-2153

64. Boomsma CM, Kavelaars A, Eijkemans MJ, Fauser BC, Heijnen CJ, Macklon NS: Ovarian stimulation for in vitro fertilization alters the intrauterine cytokine, chemokine, and growth factor milieu encountered by the embryo. Fertil Steril 2010, 94:1764-1768.

65. Masuhiro K, Matsuzaki N, Nishino E, Taniguchi T, Kameda T, Li Y, Saji F, Tanizawa O: Trophoblast-derived interleukin-1 (IL-1) stimulates the release of human chorionic gonadotropin by activating IL- 6 and IL-6-receptor system in first trimester human trophoblasts. J Clin Endocrinol Metab 1991, 72:594-601.

66. Li Y, Matsuzaki N, Masuhiro K, Kameda T, Taniguchi T, Saji F, Yone K, Tanizawa O: Trophoblast-derived tumor necrosis factor-alpha induces release of human chorionic gonadotropin using interleukin-6 (IL-6) and IL-6-receptor-dependent system in the normal human trophoblasts. J Clin Endocrinol Metab 1992, 74:184-191.

67. Uzumcu M, Coskun S, Jaroudi K, Hollanders JM: Effect of human chorionic gonadotropin on cytokine production from human endometrial cells in vitro. Am J Reprod Immunol 1998, 40:83-88. 
68. Arruvito L, Giulianelli S, Flores AC, Paladino N, Barboza M, Lanari C, Fainboim L: NK cells expressing a progesterone receptor are susceptible to progesterone-induced apoptosis. J Immunol 2008, 180:5746-5753.

69. Lai T, Wang K, Hou Q, Zhang J, Yuan J, Yuan L, You Z, Xi M: Interleukin 17 induces up-regulation of chemokine and cytokine expression via activation of the nuclear factor $\mathrm{KB}$ and extracellular signal-regulated kinase $1 / 2$ pathways in gynecologic cancer cell lines. Int J Gynecol Cancer 2011, 21:1533-1539.

70. Hatayama H, Kanzaki H, Iwai M, Kariya M, Fujimoto M, Higuchi T, Kojima K, Nakayama H, Mori T, Fujita J: Progesterone enhances macrophage colony-stimulating factor production in human endometrial stromal cells in vitro. Endocrinology 1994, 135:1921-1927.

71. Tanaka T, Sakamoto T, Umesaki N, Ogita S: Regulation of human endometrial stromal decidualization by macrophage colony-stimulating factor. Gynecol Obstet Invest 2001, 51:124-127.

72. Arcuri F, Ricci C, letta F, Cintorino M, Tripodi SA, Cetin I, Garzia E, Schatz F, Klemi P, Santopietro R, Paulesu L: Macrophage migration inhibitory factor in the human endometrium: expression and localization during the menstrual cycle and early pregnancy. Biol Reprod 2001, 64:1200-1205.

73. Lalitkumar PG, Sengupta J, Ghosh D: Endometrial tumor necrosis factor alpha (TNFalpha) is a likely mediator of early luteal phase mifepristone-mediated negative effector action on the preimplantation embryo. Reproduction 2005, 129:323-335.

74. Haider S, Knöfler M: Human tumour necrosis factor: physiological and pathological roles in placenta and endometrium. Placenta 2009, 30:111-123.

75. Sengupta J, Lalitkumar PG, Najwa AR, Charnock-Jones DS, Evans AL, Sharkey AM, Smith SK, Ghosh D: Immunoneutralization of vascular endothelial growth factor inhibits pregnancy establishment in the rhesus monkey (Macaca mulatta). Reproduction 2007, 133:1199-1211.

76. Hannan NJ, Paiva P, Meehan KL, Rombauts LJF, Gardner DK, Salamonsen LA: Analysis of fertility-related soluble mediators in human uterine fluid identifies VEGF as a key regulator of embryo implantation. Endocrinology 2011, 152:4948-4956.

77. Berndt S, Perrier d'Hauterive S, Blacher S, Péqueux C, Lorquet S, Munaut $C$, Applanat M, Hervé MA, Lamandé N, Corvol P, van den Brûle F, Frankenne F, Poutanen M, Huhtaniemi I, Geenen V, Noël A, Foidart JM: Angiogenic activity of human chorionic gonadotropin through $\mathrm{LH}$ receptor activation on endothelial and epithelial cells of the endometrium. FASEB J 2006, 20:2630-2632.

78. Abbas MM, Evans JJ, Sykes PH, Benny PS: Modulation of vascular endothelial growth factor and thymidine phosphorylase in normal human endometrial stromal cells. Fertil Steril 2004, 82(Suppl 3):1048-1053.

79. Edwards RG: Physiological and molecular aspects of human implantation. Hum Reprod 1995, 10(Suppl 2):1-13.

80. Perrier D'Hauterive S, Berndt S, Tsampalas M, Charlet-Renard C, Dubois M, Bourgain C, Hazout A, Foidart JM, Geenen V: Dialogue between blastocyst hCG and endometrial $\mathrm{LH} / \mathrm{hCG}$ receptor: which role in implantation? Gynecol Obstet Invest 2007, 64:156-160.

81. Learn CA, Mizel SB, McCall CE: mRNA and protein stability regulate the differential expression of pro- and anti-inflammatory genes in endotoxin-tolerant THP-1 cells. J Biol Chem 2000, 275:12185-12193.

82. Pratt JM, Petty J, Riba-Garcia I, Robertson DHL, Gaskell SJ, Oliver SG, Beynon $\mathrm{RJ}$ : Dynamics of protein turnover, a missing dimension in proteomics. Mol Cell Proteomics 2002, 1:579-591.

83. Fournier ML, Paulson A, Pavelka N, Mosley AL, Gaudenz K, Bradford WD, Glynn E, Li H, Sardiu ME, Fleharty B, Seidel C, Florens L, Washburn MP: Delayed correlation of mRNA and protein expression in repamycin-treated cells and a role for $\mathrm{Ggc} 1$ in cellular sensitivity to repmycin. Mol Cell Proteomics 2010, 9:271-284.

84. Kristensen AR, Gsponer J, Foster LJ: Protein synthesis rate is the predominant regulator of protein expression during differentiation. Mol Syst Biol 2013, 9:689. 10.1038/msb.2013.47.

doi:10.1186/1477-7827-11-116

Cite this article as: Srivastava et al:: Profiles of cytokines secreted by isolated human endometrial cells under the influence of chorionic gonadotropin during the window of embryo implantation. Reproductive Biology and Endocrinology 2013 11:116.

\section{Submit your next manuscript to BioMed Central and take full advantage of:}

- Convenient online submission

- Thorough peer review

- No space constraints or color figure charges

- Immediate publication on acceptance

- Inclusion in PubMed, CAS, Scopus and Google Scholar

- Research which is freely available for redistribution 